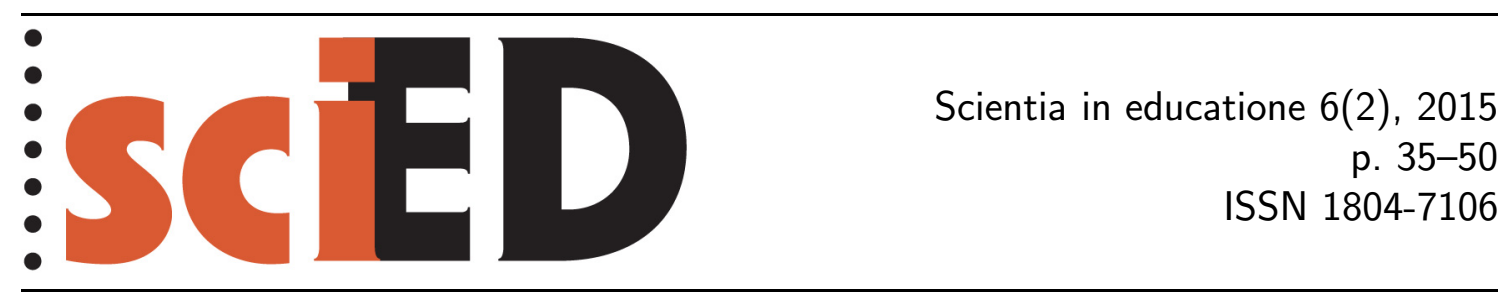

\title{
Disertační práce z didaktiky fyziky obhájené v České republice v letech 2004 až 2013 - přehled a analýza
}

\author{
Vojtěch Žák
}

\begin{abstract}
Abstrakt
Cílem této studie je analyzovat disertační práce z didaktiky fyziky obhájené v posledních letech v České republice. Strategickým cílem je reflektovat vývoj a stav didaktiky fyziky, a přispět tak $\mathrm{k}$ jejímu rozvoji (a také $\mathrm{k}$ rozvoji dalších oborových didaktik). $\mathrm{K}$ výzkumu byl použit kvalitativní přistup, metodou sběru dat byla analýza jednotlivých disertačních prací. Analyzovány byly práce obhájené v letech 2004 až 2013 na některé z českých vysokých škol. Kromě základního přehledu, jako je zejména počet prací obhájených v jednotlivých letech, se studie soustředuje na analýzu metod sběru dat použitých v disertačních výzkumech, stupeň školy (vzdělávání), jehož problematiku práce řeší, fyzikální obsah a zaměření práce z hlediska vzdělávání. Ukazuje se, že počet obhájených prací se v posledních letech obecně zvyšuje. Nejčastěji používanými metodami sběru dat jsou dotazník a didaktický test. Práce se nejvíce zaměřují na střední školy (z nich nejčastěji na gymnázia) a zabývají se různými fyzikálními oblastmi. Jsou často zaměřeny na začlenění určitého fyzikálního nebo interdisciplinárního tématu do kurikula (např. biofyziky), na hodnocení a informační technologie.
\end{abstract}

Klíčová slova: disertační práce, analýza disertačních prací, doktorské studium, didaktika fyziky, oborová didaktika, fyzikální vzdělávání.

\section{Doctoral Theses in Physics Education Defended in the Czech Republic from 2004 to 2013 Overview and Analysis}

\begin{abstract}
The purpose of the study is to analyse doctoral theses (dissertations) in the didactics of physics (physics education) defended in the Czech Republic in recent years. The strategic goal is to reflect the development and the current state of the didactics of physics and thus to contribute to its future development (and to the development of other subject didactics). The qualitative research design was used in this research. The data were collected using an analysis of particular doctoral theses defended at Czech universities between the years 2004 and 2013. Besides the basic overview, such as the number of theses defended in particular years, this study also deals with the analysis of data collection methods used in
\end{abstract}


dissertation research, the educational level at which the research questions are dealt with, physics content and the theses' focus from the education point of view. The analysis shows that the number of defended theses has been increasing in general in recent years. The most frequently used data collection methods are questionnaires and achievement tests. The theses mainly focus on the upper secondary schools (especially secondary grammar schools) and deal with various physics areas. They are often aimed at the implementation of physics or interdisciplinary topics in school curricula (e.g. biophysics), at evaluation, and at information technology.

Key words: doctoral thesis, analysis of doctoral theses, doctoral study, didactics of physics, subject didactics, physics education.

V posledních několika letech můžeme v České republice zaznamenat systematičtější zájem o reflexi didaktiky fyziky jako oboru. Dokladem toho jsou např. práce Nezvalové (2011), Dvořáka, Kekule a Žáka (2012, 2015) a Žáka (2014). Česká didaktika fyziky není v tomto úsilí osamocena; také další oborové didaktiky reflektují svůj dosavadní vývoj, pokoušejí se analyzovat současný stav, ve kterém se nacházejí, a hledají cesty svého dalšího rozvoje (Janík \& Stuchlíková, 2010; Stuchlíková \& Janík, 2011, 2015). Strategickým cílem výzkumu, jehož součástí je tato studie, je reflektovat vývoj didaktiky fyziky v Ceské republice a v zahraničí, přispět k pochopení jejího současného stavu a aktivně ovlivnit její budoucí vývoj.

Součástí hlubší analýzy stavu a vývoje oborových didaktik by zřejmě měla být také reflexe doktorského studia těchto oborů, včetně jeho produktů - disertačních prací. ${ }^{1}$ Ačkoliv byly v této oblasti v posledních letech realizovány určité kroky (Svoboda, 2005; Zpráva Akreditační komise. . ., 2010; Dvořáková \& Smrčka, 2013; Mareš, 2013), systematická reflexe samotných disertačních prací dosud chybí, a to zřejmě nejen v oblasti didaktiky fyziky, ale i v dalších oborech, včetně ostatních oborových didaktik. Cílem této studie proto je upozornit na jednotlivé disertační práce obhájené v České republice v posledních přibližně deseti letech, analyzovat je a na základě toho přispět ke zkvalitnění budoucí produkce disertačních prací v didaktice fyziky a zároveň podnítit dalšś diskuze týkající se doktorského studia.

$\mathrm{K}$ řešení tohoto úkolu se podařilo přizvat další autory, a tak paralelně $\mathrm{s}$ touto studií vznikly analýzy disertačních prací z didaktiky chemie (Rusek, 2015) a didaktiky biologie (Pavlasová, 2015). Kromě pokusu o určitý transdidaktický přesah (přinejmenším v rámci didaktik př́rodovědných oborů) má tato studie také syntetizující ambici v rámci didaktiky fyziky. Pokus o syntézu vyplývá z toho, že disertační práce z didaktiky fyziky je možné v České republice obhajovat před několika komisemi (spojenými s různými pracovišti) a chybí určitý nadhled nad těmito pracemi a jejich charakteristikami. Přehled domácích pracovište která nabízejí doktorské studium didaktiky fyziky, je uveden v tab. $1^{2}$ (Zpráva Akreditační komise..., 2010; Nezvalová, 2011: s. 186).

\footnotetext{
${ }^{1}$ Autor se tím snaží navázat na výzvu ve své předchozí práci (Žák, 2014: s. 240).

${ }^{2}$ Kromě uvedených pracovišt jsou disertační práce z didaktiky fyziky vedeny také na Pedagogické fakultě Masarykovy univerzity v Brně (jedná se o obor pedagogika).
} 
Tab. 1: Přehled domácích pracovišt nabízejících doktorské studijní obory didaktiky fyziky

\begin{tabular}{|c|c|c|}
\hline Vysoká škola, její fakulta & Studijní program & Studijní obor \\
\hline $\begin{array}{l}\text { Masarykova univerzita v Brně, } \\
\text { Přírodovědecká fakulta }\end{array}$ & Fyzika & Obecné otázky fyziky \\
\hline $\begin{array}{l}\text { Ostravská univerzita v Ostravě, } \\
\text { Přírodovědecká fakulta } \\
\text { Univerzita Hradec Králové, } \\
\text { Pedagogická fakulta } \\
\text { Západočeská univerzita v Plzni, } \\
\text { Pedagogická fakulta }\end{array}$ & $\begin{array}{l}\text { Specializace } \\
\text { v pedagogice }\end{array}$ & Teorie vzdělávání ve fyzice \\
\hline $\begin{array}{l}\text { Univerzita Karlova v Praze, } \\
\text { Matematicko-fyzikální fakulta }\end{array}$ & $\begin{array}{l}\text { Fyzika (4letý) } \\
\text { Fyzika (3letý) }\end{array}$ & $\begin{array}{l}\text { Didaktika fyziky } \\
\text { a obecné otázky fyziky } \\
\text { Obecné otázky fyziky }\end{array}$ \\
\hline $\begin{array}{l}\text { Univerzita Palackého v Olomouci, } \\
\text { Přírodovědecká fakulta }^{3}\end{array}$ & Fyzika & Didaktika fyziky \\
\hline
\end{tabular}

Protože analýza je poněkud široký pojem, bylo třeba ji přesněji specifikovat. Na základě diskuzí s dalšími didaktiky fyziky byla analýza disertačních prací vymezena následujícími úvodními a zejména výzkumnými otázkami uvedenými níže. ${ }^{4}$

Uvodní otázky mají přispět k určitému základnímu přehledu o pracích (podrobněji v oddílu 2.1):

- Kolik disertačních prací z didaktiky fyziky bylo obhájeno v jednotlivých letech?

- Jaké je zastoupení autorů-mužů a autorek-žen?

- V jakém jazyce jsou práce psány?

Výzkumné otázky se vztahují k hlubší analýze prací a reflektují odborné zájmy komunity didaktiků fyziky.

- Které metody sběru dat byly v pracích použity? (podrobněji v oddílu 2.2)

- Problematiku kterého stupně školy (vzdělávání ve fyzice) práce řeší? (2.3)

- Jaký fyzikální obsah zpracovávají? (2.4)

- Jaké je zaměření prací z hlediska vzdělávání? ${ }^{5}$ (2.5)

Analýzu metod sběru dat, které byly použity v př́slušných disertačních výzkumech, považujeme za důležitou, protože může podat obraz o metodologické úrovni prací. Rozbor zaměření prací z hlediska stupně vzdělávání potom naznačuje, jaké je propojení disertačních prací se školním vzděláváním. Analýza disertací z hlediska fyzikálního obsahu (alespoň jeho širších oblastí) může poodhalit korespondenci obsahu prací s fyzikou, nejen školskou. Odpověd' na poslední výzkumnou otázku umožní alespoň částečně nahlédnout, zda domácí disertační práce řeší obdobnou problematiku jako odborné práce z mezinárodního prostředí.

\footnotetext{
${ }^{3}$ Pracoviště spolupracuje při výchově doktorandů s Pedagogickou fakultou Masarykovy univerzity v Brně.

${ }^{4}$ Jsme si vědomi, že při analýze byl učiněn pouze úzký výběr zkoumaných aspektů, nicméně zájemcům o provedení dalších analýz mohou pomoci informace uvedené v této studii.

${ }^{5}$ Zaměřením z hlediska vzdělávání se zde míní kategorie překračující fyzikální vzdělávání směrem k šiř̉eji pojatému vzdělávání, např. vyučování, informační technologie ve vzdělávání, neformální výuka atd. (podrobněji v části 2.5).
} 


\section{Metodologie}

Z metodologického hlediska byl použit v podstatě kvalitativní přístup ${ }^{6}$. Data byla sbírána na základě analýzy jednotlivých disertačních prací. Té byly podrobeny disertační práce obhájené na některém z českých pracovišt' (nemuselo se ovšem jednat o práce napsané v českém jazyce), tematicky spadající do oblasti didaktiky fyziky a s datem obhajoby v letech 2004 až 2013 (včetně obou let). ${ }^{7}$

Prvním krokem byla analýza abstraktů, př́íp. anotací a klíčových slov (pokud byly tyto části $\mathrm{k}$ dispozici), dále se pokračovalo analýzou úvodních a závěrečných částí a poté se pozornost zaměřila na další kapitoly práce. Tento postup umožnil pozornost lépe nasměrovat $\mathrm{k}$ řešení stanovených výzkumných otázek, protože se začalo analýzou těch částí prací, které typicky již obsahují nosné informace o práci, jejím pojetí a obsahu.

Protože jsou známa pracoviště realizující doktorské studijní programy (tab. 1), byly práce vyhledávány nejprve prostřednictvím webových stránek knihoven příslušných fakult. $\mathrm{V}$ některých případech se podařilo práce vyhledat jen s využitím informací na těchto webových stránkách, a nebylo tudíž třeba s nikým osobně komunikovat. $\mathrm{V}$ jiných př́padech bylo nutné kontaktovat přes webové stránky knihovníka či knihovnici, kteří poskytli informace vedoucí k disertačním pracím. V jednom případě byla nutná osobní návštěva studovny v knihovně, do které byly hledané práce zapůjčeny, protože neexistovaly v elektronické podobě. Jiná knihovna poskytla některé disertační práce na $\mathrm{CD}$. Ani přes toto úsilí se bohužel některé disertační práce nepodařilo sehnat; jejich exempláře nejsou (př́ip. jejich existence není známa) ani v příslušné fakultní knihovně, ani na příslušné katedře. Ve dvou případech nemají kompletní elektronickou verzi ani autoři prací. Tyto potíže se týkají zejména starších prací. $^{8}$ Další komplikace při vyhledávání prací byla dána tím, že v rámci studijního oboru s názvem obecné otázky fyziky (jedná se o pracoviště v Brně a v Praze, tab. 1) některé práce nespadaly z hlediska svého zaměření do didaktiky fyziky, ale spíše do fyziky. Takové práce analyzovány nebyly. Dále bylo zjištěno, že v př́ipadě Masarykovy univerzity v Brně některé práce spadají pod Pedagogickou fakultu, nikoli pod Př́rodovědeckou fakultu (srov. Zpráva Akreditační komise. ., 2010 a poznámka 2).

\section{VÝSLEDKY}

\subsection{ZÁKLADNí ÚDAJE O DISERTAČNÍCH PRACÍCH}

Podle dostupných údajů bylo v letech 2004 až 2013 (včetně obou let) obhájeno v oblasti didaktiky fyziky v České republice 61 disertačních prací. Z nich se analýze podařilo podrobit 56 prací (přes $90 \%$ ). Seznam jejich názvů a autorů je uveden v př́loze (tab. 8 až 14$)$.

\footnotetext{
${ }^{6} \mathrm{O}$ kvalitativním přístupu zde mluvíme, i když je z následujícího patrné, že výsledky jsou částečně vyjádřeny kvantitativně (počty prací, relativní četnosti). Podstatou tohoto výzkumu ovšem je, že se rozkryly a identifikovaly určité kategorie (jejich výskyt).

${ }^{7}$ Zkoumané období bylo zvoleno tak, aby se jednalo o deset dokončených let. Vzhledem k tomu, že se s přípravami této analýzy začalo v roce 2014, byl zvolen interval 2004 až 2013. Připomeňme, že tradice disertačních prací v oblasti didaktiky fyziky má v České republice (resp. bývalém Československu) mnohem delší trvání. Komise pro obhajoby tehdejších kandidátských disertačních prací z teorie vyučování fyzice byla zřízena už v roce 1966 (Fenclová, 1982: s. 17).

${ }^{8} \mathrm{Na}$ uvedené problémy spojené s (ne)dostupností prací reagujeme v závěrečné části studie.
} 
Tab. 2: Počet obhájených disertačních prací v jednotlivých letech

\begin{tabular}{cc}
\hline Rok obhajoby & Počet prací \\
\hline 2004 & 4 \\
\hline 2005 & 4 \\
\hline 2006 & 3 \\
\hline 2007 & 3 \\
\hline 2008 & 4 \\
\hline 2009 & 11 \\
\hline 2010 & 6 \\
\hline 2011 & 11 \\
\hline 2012 & 6 \\
\hline 2013 & 9 \\
\hline
\end{tabular}

V tabulce 2 je uveden počet prací, které byly obhájeny v jednotlivých letech zkoumaného období let 2004 až 2013. Ukazuje se, že počty značně kolísají (pouze tři práce obhájené v roce 2006 a 2007 a jedenáct prací v letech 2009 a 2011). Rozdělíme-li zkoumané období do dvou stejně dlouhých intervalů, zjistíme, že v letech 2004 až 2008 bylo obhájeno 18 prací (tři nebo čtyři práce ročně), zatímco v období 2009 až 2013 to bylo 43 prací (od šesti do jedenácti ročně). Je tedy zřejmé, že publikační výkon je z hlediska kvantity $\mathrm{v}$ posledních letech výrazně větší než v letech předcházejících.

Počty autorek a autorů analyzovaných prací jsou poměrně vyrovnané; jedná se o 24 žen a 32 mužů, tj. $43 \%$ a $57 \%{ }^{9}$. Naprostá většina prací je psána v českém jazyce (52 prací, tj. asi $93 \%$ ), tři práce jsou psány anglicky (z toho jedna částečně polsky) a jedna slovensky.

\subsection{METODY SBĚRU DAT}

Za důležitou charakteristiku disertačních prací, které by měly být v zásadě výzkumnými pracemi, můžeme považovat informaci, které metody sběru dat byly použity v přislušných disertačních výzkumech. Při analýze disertačních prací z tohoto hlediska jsme vyšli z přehledu a vymezení metod, které uvádí Chráska (2009: s. 815-816), Hendl (2009: s. 821) a Fenclová (1982: s. 110-112).

Z tabulky 3 je zřejmé, že nejčastěji používanými metodami sběru dat jsou dotazník a didaktický test. Výrazně méně je využívána analýza textů, učebnic, kurikulárních dokumentů a prací žáků, ještě méně pozorování a interview. Z předchozí tabulky je zřejmé, že v některých pracích bylo použito více metod sběru dat, protože v 56 disertačních pracích bylo identifikováno celkem 89 metod.

Tab. 3: Metody sběru dat použité v disertačních pracích

\begin{tabular}{lrr}
\hline Metoda sběru dat & $\begin{array}{c}\text { Absolutní } \\
\text { četnost }\end{array}$ & $\begin{array}{c}\text { Relativní } \\
\text { četnost }\end{array}$ \\
\hline dotazník & 36 & $41 \%$ \\
\hline didaktický test & 27 & $30 \%$ \\
\hline analýza textů, učebnic, kurikulárních dokumentů, prací žáků $^{\prime}$ & 10 & $11 \%$ \\
\hline pozorování10 $^{10}$ & 8 & $9 \%$ \\
\hline interview & 8 & $9 \%$ \\
\hline celkem metod sběru dat ve všech 56 pracích & 89 & $100 \%$ \\
\hline
\end{tabular}

\footnotetext{
${ }^{9}$ Od tohoto místa v textu pracujeme již jen s 56 pracemi, které bylo možné analyzovat.

${ }^{10}$ Mezi pozorování byla zařazena také videostudie, i když jsme si vědomi, že se obě metody zcela nekryjí (jedná se o případy dvou disertačních prací).
} 
Tab. 4: Rozdělení disertačních prací podle počtu metod sběru dat

\begin{tabular}{ccc}
\hline $\begin{array}{c}\text { Počet metod použitých } \\
\text { v dané práci }\end{array}$ & $\begin{array}{c}\text { Absolutní } \\
\text { četnost }\end{array}$ & $\begin{array}{c}\text { Relativní } \\
\text { četnost }\end{array}$ \\
\hline jedna & 19 & $34 \%$ \\
\hline dvě & 17 & $30 \%$ \\
\hline tři & 8 & $14 \%$ \\
\hline čtyři & 3 & $6 \%$ \\
\hline žádná & 9 & $16 \%$ \\
\hline & &
\end{tabular}

Z tabulky 4 je patrné, že přibližně v třetině disertačních prací byla použita právě jedna metoda sběru dat, v necelé třetině prací se kombinovaly dvě metody a v jedné pětině prací se objevilo více metod (tři nebo čtyři). Zároveň se ukázalo, že zhruba v šestině prací nebyla použita žádná metoda sběru dat.

\subsection{STUPEŇ ŠKOLY}

Pokud jde o stupeň školy (stupeň vzdělávání), na který je práce zaměřena, ukazuje se (tab. 5), že disertační práce řeší problematiku vzdělávání zejména na středních školách (téměř $49 \%$, z toho se většina týká gymnázií), dále na základních školách (přibližně $31 \%$ ) a méně na vysokých školách (asi $16 \%$ ). V případě některých prací se jedná pouze o zacílení do př́slušné věkové kategorie žáků nebo studentů, ale jde o vzdělávání v mimoškolním prostředí. Takové práce jsou ovšem v tabulce 5 zařazeny k odpovídajícímu stupni školy. Pokud se zaměřuje disertační práce na více než dva stupně škol, př́íp. není možné ji z jiného důvodu zařadit do předchozích kategorií, je uvedena mezi ,jinéc.

Tab. 5: Rozdělení disertačních prací podle stupně vzdělávání (školy), jehož problematiku řeši

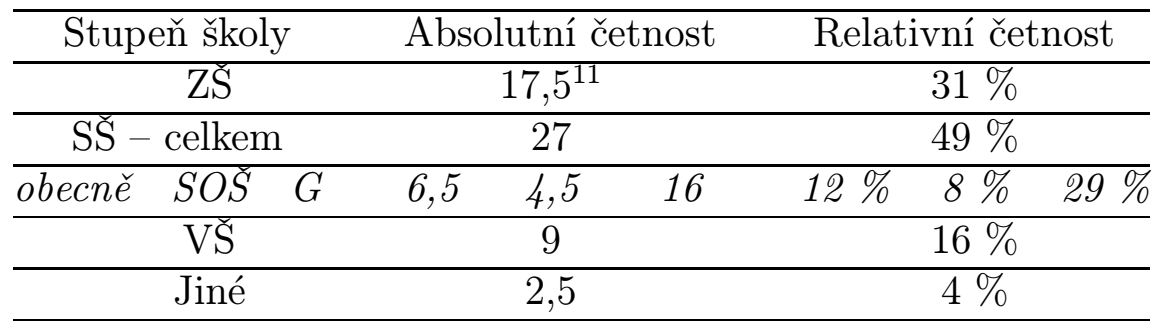

\subsection{FYZIKÁLNÍ OBSAH}

Určitou informaci o analyzovaných disertačních pracích podává také to, jaký fyzikální obsah dané práce zpracovávají. Toto hledisko je poněkud problematické, protože podstatou mnoha prací není samotný fyzikální obsah, tj. toto hledisko pro

\footnotetext{
${ }^{11}$ Polovina znamená, že fyzikálnímu vzdělávání na daném stupni školy se práce věnuje částečně a částečně se také věnuje jinému stupni školy. Podrobnější komentář k určování četností v tab. 5 a v dalších: Každá práce má váhu rovnou 1. Pokud se práce zaměřuje na jeden stupeň školy (vzdělávání), je váha 1 přiřazena $\mathrm{k}$ danému stupni v tab. 5. Pokud práce řeší problematiku dvou stupňů, je rovnoměrně, tj. vahou 0,5 započítána v tab. 5 ke každému z obou stupňů. Pokud řeší práce problematiku více než dvou stupňủ, je zařazena mezi ,jiné“. To považujeme za nejjednodušší způsob, jak je možné vyjádřit, kterými stupni školy a do jaké míry se disertační práce zabývají. Z hlediska celkových výsledků a jejich diskuze mají význam především relativní četnosti. Limitem tohoto postupu je nicméně to, že nezohledňuje fakt, že některé práce, které řeší problematiku dvou stupňů, se jednomu z nich věnují více než druhému.
} 
ně není př́liš důležité. Navíc v některých pracích není možné dominantní fyzikální téma jednoznačně identifikovat, protože je v nich zpracováno více témat. Na druhou stranu pro vzdělavatele, kteří hledají inspiraci k výuce jednotlivých fyzikálních témat, a také pro případné zájemce z komunity fyziků mohou být níže uvedené informace přínosem. $\mathrm{V}$ tabulce 6 jsou uvedeny rámcové fyzikální obsahy a příslušná četnost prací, které se jimi zabývají. Kategorie „jiné“ zahrnuje práce, ve kterých žádný fyzikální obsah nedominuje.

Tab. 6: Rozdělení disertačních prací podle fyzikálního obsahu, kterému se věnují

\begin{tabular}{ll}
\hline Fyzikální obsah ${ }^{12}$ & $\begin{array}{c}\text { Absolutní } \\
\text { četnost prací }\end{array}$ \\
\hline mechanika & 9 \\
\hline molekulová fyzika a termika & $5,5^{13}$ \\
\hline elektřina a magnetismus & 5 \\
\hline biofyzika & 4 \\
\hline optika & 3,5 \\
\hline astronomie a astrofyzika & 3 \\
\hline fyzika mikrosvěta & 3 \\
\hline meteorologie & 1 \\
\hline jiné & 22 \\
\hline
\end{tabular}

Zjištěné informace o fyzikálním obsahu řešeném v disertačních pracích můžeme porovnat se vzdělávacím obsahem (oblastmi) fyziky na 2. stupni základní školy a na středních školách. Těmito dvěma stupni škol se disertační práce zabývaly nejčastěji (viz tab. 5). I když jsou oblasti školské fyziky v současných kurikulárních dokumentech označovány jinou terminologií, než je uvedeno v Tab. 6 (podrobněji $R V P$ $Z V, 2013:$ s. 53-55 a RVP G, 2007: s. 27-29), v hrubém přiblížení můžeme říci, že všemi oblastmi fyziky na základní a střední škole se disertační práce z didaktiky fyziky do nějaké míry zabývají. ${ }^{14}$ Neméně podstatné ovšem je, že některé disertační práce zpracovávají témata, která překračují běžné vymezení školské fyziky. Jedná se o biofyziku, zpracovanou ve čtyřech pracích, a meteorologii, kterou se zabývá jedna disertační práce.

\subsection{ZAMĚŘENÍ Z HLEDISKA VZDĚLÁVÁNí}

V této části textu se pokusíme alespoň dílčím způsobem uvést do vztahu zaměření českých disertačních prací se zaměřením odborných publikací v mezinárodním prostředí. Porovnání provedeme na základě různých zaměření, která převzali a upravili Tsai a Wen (2005) a dále využili Lee et al. (2009), srov. Kekule (2014: s. 45-46). Přestože jsme si vědomi rezerv tohoto srovnání (jedná se o zaměření prací z širší oblasti science education; ne o disertační práce, ale práce ve vybraných časopisech a dále o práce z období, které není totožné se zkoumaným intervalem 2004 až 2013), považujeme za podnětné toto porovnání provést. $\mathrm{V}$ tabulce 7 jsou uvedena různá zaměření prací, která byla identifikována v mezinárodním prostředí, a jsou u nich uvedeny počty českých disertačních prací z didaktiky fyziky, které jim odpovídají.

\footnotetext{
${ }^{12}$ Jednotlivé oblasti fyzikálního obsahu jsou v této tabulce vymezeny tradičně (až na meteorologii a biofyziku); do značné míry kopírují historický vývoj fyziky a rozdělení školské fyziky.

${ }^{13}$ Analogicky jako v poznámce 11 .

${ }^{14}$ Zdůrazněme, že výše uvedené porovnání je jen velmi hrubé. Nelze doložit, že by jednotlivé oblasti v RVP ZV a v RVP G byly disertačními pracemi pokryty rovnoměrně; naopak, některé z nich jsou v nich řešeny jen okrajově. Uvedené hrubé přiblížení tak pouze naznačuje, že disertační práce se žádné hlavní oblasti školské fyziky v zásadě nevyhýbají.
} 
Tab. 7: Rozdělení disertačních prací podle zaměření z hlediska vzdělávání

\begin{tabular}{lcc}
\hline Téma z hlediska vzdělávání & $\begin{array}{c}\text { Absolutní } \\
\text { četnost prací }\end{array}$ & $\begin{array}{c}\text { Relativní } \\
\text { četnost }\end{array}$ \\
\hline vzdělávání učitelů & 1 & $2 \%$ \\
\hline vyučování & $10,5^{15}$ & $19 \%$ \\
\hline učení - koncepce & 7 & $13 \%$ \\
\hline učení - kontext & 4 & $7 \%$ \\
\hline cíle, vzdělávací politika, kurikulum a hodnocení & 16 & $28 \%$ \\
\hline kultura, společnost a gender & 0 & $0 \%$ \\
\hline filozofie, historie, epistemologie a podstata věd & 0 & $0 \%$ \\
\hline informační technologie ve vzdělávání & 16 & $28 \%$ \\
\hline neformální výuka & 1,5 & $3 \%$ \\
\hline
\end{tabular}

Z tabulky 7 je zřejmé, že více než čtvrtina zkoumaných disertačních prací je zaměřena na cíle, vzdělávací politiku, kurikulum a hodnocení a stejné je zastoupení prací zaměřených na informační technologie ve vzdělávání. První jmenované téma je ovšem vymezeno poměrně široce a bližší pohled na disertační práce ukazuje, že jsou zaměřeny hlavně na začlenění určitého fyzikálního nebo interdisciplinárního tématu do kurikula (např. nanotechnologie, entropie, biofyzika, astronomie, meteorologie, geografie) a na hodnocení (zejména znalostí a dovedností žáků). Téma informačních technologií je syceno zejména konkrétními náměty na jejich využití ve výuce fyziky.

$\mathrm{Na}$ druhou stranu jen sporadicky se disertační práce věnovaly neformální výuce a vzdělávání učitelí. Mezi zkoumanými pracemi nebyla dokonce nalezena žádná, která by se orientovala na kulturu, společnost a gender nebo filozofii, historii, epistemologii a podstatu věd.

\section{ZÁVĚR A DISKUZE}

Je zřejmé, že doktorské studium v didaktice fyziky se v posledních letech z hlediska určitých kvantitativních parametrů zdárně vyvíjí. Svědčí o tom například vzrůstající počet disertačních prací obhájených v nedávném období. Zatímco v letech 2004 až 2008 byly obhájeny ročně tři až čtyři práce, v období 2009 až 2013 to bylo od šesti do jedenácti prací ročně. Určité dílčí porovnání je možné provést se starším obdobím, kdy podle Fenclové (1982: s. 17) bylo od roku 1966 do začátku 80. let 20. století v bývalém Československu obhájeno 15 tehdejších kandidátských prací z oboru teorie vyučování fyzice. Také z tohoto důvodu je oprávněné mluvit o kvantitativním nárůstu. Tento fakt můžeme považovat za potenciálně pozitivní z toho důvodu, že se tak může do budoucna zvětšit a zkvalitnit základna odborníků, kteří budou dále didaktiku fyziky a obecněji vzdělávání ve fyzice rozvíjet. Přestože je zřejmé, že zdaleka ne všichni autoři úspěšně obhájených disertačních prací zůstávají v oblasti didakticko-fyzikálního výzkumu, i pro jejich práci, např. jako učitelů na základních a středních školách, mohou být nabyté zkušenosti využitelné. Je ovšem otázkou do diskuze, zda má být profil absolventa doktorského studia didaktiky fyziky takový, aby se dále výzkumně didaktikou fyziky zabýval, např. na vysoké škole, nebo má-li se spíše stát „výzkumem více políbeným“ učitelem fyziky na základní nebo střední škole. První varianta by sice zřejmě vedla k poklesu kvantity (počtu absolventů),

\footnotetext{
${ }^{15}$ Analogicky jako v poznámce 11.
} 
na druhou stranu by umožnila více koncentrovat síly školitelů a konzultantů těchto studentů a mohla by znamenat kvalitativní posun v oboru.

Autory disertačních prací jsou poměrně vyrovnaně jak muži, tak ženy, i když muži poněkud převažují. ${ }^{16}$ Překvapivým zjištěním není, že naprostá většina prací je psána česky, pouze tři práce anglicky (z nich jedna částečně polsky) a jedna práce slovensky. Otázka jazyka práce není úplně okrajová, protože anglicky psané odborné texty mají potenciál proniknout do mezinárodního prostředí. Zejména tehdy, pokud je podstatná část literatury zjištěné při rešerši psána anglicky, nabízí se možnost psát práci v angličtině poměrně přirozeně. $\mathrm{V}$ tomto vidíme určitou rezervu a výzvu domácí didaktice fyziky. $\mathrm{Na}$ druhou stranu lze pochopitelně vytvořit nosný text v angličtině určený do mezinárodního časopisu i na základě disertační práce napsané česky.

Pokud jde o metody sběru dat použité v disertačních pracích, nejčastěji se vyskytovaly dotazníky a didaktické testy. Je třeba zdůraznit, že použité dotazníky a didaktické testy nebyly často standardizované. Tady je vidět velká rezerva domácích disertačních výzkumů, a sice že nástroje ke sběru dat jsou často vytvářeny ad hoc, bez hlubšího metodologického opodstatnění. Data získaná díky těmto nástrojům jsou pak často nekvalitní. I když nelze obecně považovat určitou metodu sběru dat za lepší než jinou, je vhodné upozornit i na jiné metody, než které v českých disertacích dominovaly - např. pozorování, různé podoby interview, na analýzu nejrůznějších textů, ale také metodu sémantického diferenciálu, analýzu audiovizuálních materiálů apod. Ty byly používány výrazně méně často (některé vůbec ne), přestože i ony mohou významně přispět k získání relevantních dat.

Také v disertačních pracích $\mathrm{z}$ didaktiky biologie a chemie se dotazník objevoval jako nejčastější metoda sběru dat (Pavlasová, 2015; Rusek, 2015). Didaktický test byl ale používán $\mathrm{v}$ didaktice chemie a biologie méně než $\mathrm{v}$ didaktice fyziky. $\mathrm{V}$ případě disertačních prací z didaktiky chemie byl odsunut na třetí místo za obsahovou analýzu (podrobněji Rusek, 2015) a disertační práce z didaktiky biologie častěji než didaktický test využívaly nejen obsahovou analýzu dokumentů, ale i pozorování (podrobněji Pavlasová, 2015). Obdobně dominuje dotazník jako metoda sběru dat v českém pedagogickém výzkumu (srov. Průcha, 2009: s. 807).

Na základě analýzy disertačních prací je zřejmé, že v některých z nich byl výzkum proveden ve značně redukované podobě, někdy snad jen z formálních důvodů. $\mathrm{S}$ tím souvisí počet metod sběru dat, které byly použity v jednotlivých disertačních pracích. Za potenciálně hodnotné můžeme považovat fakt, pokud je v daném výzkumu použito více metod sběru dat. Tím může dojít k tzv. triangulaci (Švaříček, 2014: s. 202-206), která může vést $\mathrm{k}$ dosažení větší důvěryhodnosti výsledků a ke zvýšení kvality výzkumu. Tuto naději dává asi polovina disertačních prací, kde se objevují dvě nebo více metod sběru dat. Přibližně v třetině disertačních prací byla použita jen jedna metoda sběru dat. Tyto práce nemůžeme samozřejmě považovat obecně za méně kvalitní, jen upozorňujeme, že je možné a vhodné metody sběru dat kombinovat. Zarážející je ovšem devět disertačních prací, kde nebyla použita žádná metoda sběru dat, příp. jen ve velmi redukované podobě. Je otázkou, v čem spočívá hodnota těchto prací, když lze pochybovat o jejich výzkumném charakteru.

Ačkoliv je potenciálně přínosné, aby disertační práce poskytovaly inovace fyzikálnímu vzdělávání, domníváme se, že disertační práce by měly mít i v těchto případech

\footnotetext{
${ }^{16}$ Relativně vyrovnaný počet mužů a žen může souviset $\mathrm{s}$ tím, že didaktika fyziky je obor, který těsně souvisí jak s fyzikou (tradičně více spojovanou s muži), tak pedagogikou (asociovanou více se ženami).
} 
výzkumný charakter. Koneckonců obhájení disertační práce je nutnou podmínkou k získání akademicko-vědeckého titulu Ph.D. Metodologická neukotvenost mnoha disertačních prací se projevuje také tak, že v nich není formulováno, jak je daný výzkum orientován (kvalitativní, kvantitativní, smíšený přístup), a nebývá ani blíže vyjasněn design výzkumu.

Z hlediska stupně školy řeší disertační práce nejčastěji problematiku fyzikálního vzdělávání na středních školách, dále na základních školách a méně na vysokých školách. Pokud jde o disertační práce, které se zabývají středním stupněm vzdělávání, podstatná část z nich se zabývá speciálně gymnázii, zatímco jen malá část (skoro čtyřikrát méně) řeší problematiku středních odborných škol (SOŠ). Přitom na SOŠ se vzdělává více studentů než na gymnáziích (Statistická ročenka školství. ., 2015). I když můžeme přijmout fakt, že na mnoha SOŠ je fyzika jen okrajovým předmětem, domníváme se, že disertační práce by měly tuto problematiku řešit více. Určitou komplikací (a zároveň výzvou) zde může být existence desítek různých oborů v rámci SOŠ. V posledních letech se také ukazuje, že některé prvky fyzikálního (a obecněji přírodovědného) vzdělávání pronikají do vzdělávání a výchovy $\mathrm{v}$ mateřských školách a na druhou stranu také do vzdělávání dospělých, např. v science centrech nebo v rámci univerzity třetího věku. Je otázkou, zda se také vzdělávání ve fyzice těchto věkových kategorií ukáže časem jako nosné pro disertační práce ${ }^{17}$.

Na základě analýzy disertačních prací z hlediska fyzikálního obsahu je možné říci, že práce velmi zhruba pokrývají všechny hlavní oblasti školské fyziky jak na základních školách, tak na středních školách. Mezi disertačními pracemi se objevily i takové, které překračují rámec školské fyziky vymezený v současných kurikulárních dokumentech (zejména RVP) - práce zaměřené na biofyziku a meteorologii. Tyto práce by tedy mohly být využitelné při integraci fyziky s dalšími přírodovědnými obory ve výuce a obecně při inovaci obsahu školské fyziky.

Pokud porovnáváme zaměření českých disertačních prací se zaměřením odborných publikací v mezinárodním prostředí (podrobnější vymezení v části 2.5), ukazuje se, že zatímco mimo Českou republiku se objevují také publikace zaměřené na kulturu, společnost, gender a na filozofii, historii, epistemologii a podstatu věd (srov. Kekule, 2014: s. 46), žádná česká disertační práce z didaktiky fyziky takto zaměřena nebyla. Obdobně menší zájem byl věnován vzdělávání učitelů a učení - kontextu. Naopak v domácím prostředí byla větší pozornost než v mezinárodním směrována k informačním technologiím ve vzdělávání a ke kurikulu a hodnocení. Zdá se, že se v českém prostředí méně orientujeme na širší souvislosti fyzikálního vzdělávání a více tíhneme k samotné školní výuce fyziky, jejím prostředkům a obsahům.

Cílem této studie není hodnotit jednotlivé disertační práce z hlediska jejich odborné kvality. Jak bylo uvedeno výše, všechny analyzované práce byly obhájeny, a lze tedy předpokládat, že vykazují určitou kvalitu. Na druhou stranu je možné představit některé náměty do diskuze o rozvoji kvality disertačních prací, ke kterým je možné dospět na základě provedené analýzy.

Při analýze prací se ukázalo, že přibližně šestina z nich neobsahuje abstrakt (nebo jemu odpovídající text) a asi v třetině prací nejsou uvedena klíčová slova. Přitom existence těchto částí výrazně usnadňuje získání základních informací o textu a přispívá významně k orientaci v něm. Dalším podnětem do diskuze je postřeh autora této analýzy, že výzkumné části nebyla v některých disertačních pracích věnována dostatečná pozornost. Svědčí o tom neorganické začlenění informací o výzkumu do

\footnotetext{
${ }^{17}$ Obdobně se nabízí zabývat se fyzikálním vzděláváním např. v základních školách speciálních, učilištích atd.
} 
struktury práce, chybějící zdůvodnění použité metodologie, nevyjasnění vztahu zamýšleného výzkumu $\mathrm{k}$ již provedeným obdobným výzkumům atd. Připomeňme výše uvedené zjištění, že přibližně v $16 \%$ prací nebyla použita v podstatě žádná metoda sběru dat, což v případě těchto prací znamená, že nemají výzkumný charakter. Takové práce se zřejmě orientují na inovaci či vývoj, ale bez výzkumně zakotvené opory. Ale ani práce, ve kterých byla použita některá metoda sběru dat, nejsou bez problémů. Ve většině z nich chybí základní metodologické informace, zejména o metodologickém přístupu (kvantitativní, kvalitativní, smíšený) a o designu výzkumu. Informace o metodologii se tak často redukují jen na metodu sběru dat (zde dominuje nestandardizovaný dotazník). Jako problematický moment můžeme vnímat také to, že v disertačních pracích nebývá vyjasněn strategický cíl výzkumu, ke kterému má ambici práce přispět, a někde není explicitně uveden ani cíl disertační práce. S tím souvisí mnohdy nevhodné vymezení (někdy dokonce „nevymezení“) výzkumného problému. Právě v oblasti metodologického uchopení můžeme spatřovat největší rezervy analyzovaných prací. Připomeňme na tomto místě názor Dvořákové a Smrčky (2013: s. 401):

Cílem studia v doktorském programu není získávání vědomostí, které se dají jednoduše využít v praktickém životě, doktorský program nemůže ani nahradit profesní vzdělávání, kterého je třeba k výkonu povolání mimo sféru výzkumu a vysokého školství. Posláním doktorského programu je náročná individuální vědecká příprava s důrazem na metodologii vědy a schopnost realizace základního výzkumu.

Pokud se s tímto názorem ztotožňujeme, je otázkou, do jaké míry se nám jako pracovníkům participujícím v doktorském studiu daří tento cíl podporovat.

Je zřejmé, že provedené analýzy nejsou jediné možné a vyčerpávající. Právě z důvodu, aby byly disertační práce dostupnější i dalším zájemcům, např. studentům doktorského studia, jejich školitelům, dalším výzkumníkům apod., je v př́loze níže (tab. 8 až 14) uveden seznam disertačních prací z didaktiky fyziky, které byly v letech 2004 až 2013 v České republice obhájeny. Dalším záměrem je vytvořit webové prostředí, které by prostřednictvím odkazů vedlo k jednotlivým disertačním pracím (jejich plným verzím). Práce by zde mělo být možné vyhledávat zejména podle těch aspektů, které byly zkoumány v rámci této studie. Je snaha, aby také práce obhájené po roce 2013 byly systematicky do tohoto prostředí zařazovány, a aby tedy bylo aktuální. Disertační práce by tak mohly více vystoupit z pomyslné šedé zóny odborné literatury a mohla by se zvětšit pravděpodobnost jejich využití jak v dalším výzkumu, tak v praxi.

V souvislosti se zkoumáním disertačních prací se otevírají další otázky a možné výzkumné výzvy. Např. je otázkou, jaká část absolventů doktorského studia (vymezení užšího pojmu postdoktorand a některé analýzy pro program Pedagogika viz Mareš, 2013) zůstává aktivními členy komunity didaktiků fyziky a jakými publikacemi se profiluje jejich odborná činnost. K první otázce lze odpověd’ zhruba naznačit: Podle účasti na celostátní konferenci se zahraniční účastí Moderní trendy v př́pravě učitelů fyziky 7 (Kašperské Hory, 27.-29. 4. 2015), které se zúčastnilo osm z jedenašedesáti autorů obhájených prací, lze soudit, že ne zdaleka všichni v oboru didaktiky fyziky zůstávají. 


\section{LITERATURA}

Dvořák, L., Kekule, M. \& Žák, V. (2012). Výzkum v oblasti fyzikálního vzdělávání - co, proč a jak. Ceskoslovenský časopis pro fyziku, 62(5-6), 325-330.

Dvořák, L., Kekule, M. \& Žák, V. (2015). Didaktika fyziky včera, dnes a zítra. In I. Stuchlíková \& T. Janík (Eds.), Oborové didaktiky: vývoj - stav-perspektivy (123-157). Brno: Masarykova univerzita.

Dvořáková, V. \& Smrčka, J. (2013). Hodnocení kvality doktorských studijních programů na vysokých školách v ČR. Pedagogika, 63(3), 393-403.

Fenclová, J. (1982). Úvod do teorie a metodologie didaktiky fyziky. Praha: Státní pedagogické nakladatelství.

Hendl, J. (2009). Kvalitativní pedagogický výzkum. In J. Průcha (Ed.), Pedagogická encyklopedie (819-823). Praha: Portál.

Chráska, M. (2009). Kvantitativní pedagogický výzkum. In J. Průcha (Ed.), Pedagogická encyklopedie (813-818). Praha: Portál.

Janík, T. \& Stuchlíková, I. (2010). Oborové didaktiky na vzestupu: přehled aktuálních vývojových tendencí. Scientia in educatione, 1(1), 5-32.

Kekule, M. (2014). Obsahová analýza klíčových témat výzkumu v př́rodovědném vzdělávání. Scientia in educatione, 5(2), 40-57.

Lee, M., Wu, Y. \& Tsai, C. (2009). Research trends in science education from 2003 to 2007: A content analysis of publications in selected journals. International Journal of Science Education, 31(15), 1999-2 020.

Mareš, J. (2013). Neviditelná skupina aneb Co s postdoktorandy? Pedagogická orientace, 23(1), 5-26.

Nezvalová, D. (2011). Didaktika fyziky v Ceské republice: trendy, výzvy a perspektivy. Pedagogická orientace, 21(2), 171-192.

Pavlasová, L. (2015). Disertační práce se zaměřením na didaktiku biologie v Ceské republice v letech 2004-2013. Scientia in educatione, 6(2), 4-15.

Průcha, J. (2009). Pedagogický výzkum v ČR. In J. Průcha (Ed.), Pedagogická encyklopedie (803-808). Praha: Portál.

Rusek, M. (2015). Analýza disertačních prací z didaktiky chemie obhájených v letech 2003-2014. Scientia in educatione, 6(2), 16-34.

RVP G. Rámcový vzdělávací program pro gymnázia (2007). Praha: Výzkumný ústav pedagogický v Praze.

RVP ZV. Rámcový vzdělávací program pro základní vzdělávání (verze platná od 1. 9. 2013) (2013). Praha: MŠMT.

Statistická ročenka školství - výkonové ukazatele 2014/15. (2015). Praha: MŠMT.

Dostupné z http://www.msmt.cz/vzdelavani/skolstvi-v-cr/statistika-skolstvi/statistickarocenka-skolstvi-vykonove-ukazatele-2014-15

Stuchlíková, I. \& Janík, T. (Eds.). (2011). Oborové didaktiky: bilance a perspektivy [Monotematické číslo]. Pedagogická orientace, 21(2).

Stuchlíková, I. \& Janík, T. (Eds.). (2015). Oborové didaktiky: vývoj - stav - perspektivy. Brno: Masarykova univerzita. 
Svoboda, E. (2005). Vědecká základna didaktiky fyziky. In D. Nezvalová (Ed.), Sborník $z$ konference: Projekty $v$ teorii a praxi vyučování fyzice (20-26). Olomouc: Univerzita Palackého v Olomouci.

Švaříček, R. (2014). Triangulace. In R. Švaříček \& K. Šed’ová (Eds.), Kvalitativní výzkum v pedagogických vědách (202-206). Praha: Portál.

Tsai, C.-C. \& Wen, L. M. C. (2005). Research and trends in science education from 1998 to 2002: A content analysis of publications in selected journals. International Journal of Science Education, 27, 3-14.

Zpráva Akreditačni komise o hodnocení doktorských studijních programů z oblasti oborových didaktik př́rodních věd (2010). Dostupné z http://www.akreditacnikomise.cz/attachments/231_hodnoceni_dsp_didaktiky_2010.pdf Žák, V. (2014). Historický vývoj pojetí didaktiky fyziky v České republice. Pedagogická orientace, 24(2), 222-243.

VoJTĚCH ŽÁK, Vojtech.Zak@mff.cuni.cz Univerzita Karlova v Praze, Matematicko-fyzikální fakulta Katedra didaktiky fyziky V Holešovičkách 2, 18000 Praha 8, Česká republika 


\section{Př́́LOHA}

Seznam názvů disertačních prací z didaktiky fyziky, které byly obhájeny v České republice v letech 2004 až 2013, a jejich autorů (práce jsou řazeny ve stejném pořadí jako fakulty v tab. $1^{18}$, dále chronologicky podle data obhajoby na dané fakultě a následně abecedně podle př́ijmení autora $)^{19}$

Tab. 8: Př́rodovědecká fakulta Masarykovy univerzity v Brně

\begin{tabular}{llc}
\hline Název práce & $\begin{array}{c}\text { Jméno } \\
\text { autora/autorky }\end{array}$ & $\begin{array}{c}\text { Rok } \\
\text { obhajoby }\end{array}$ \\
\hline Demonstrační experimenty ve fyzice a jejich interpretace & Bartoš J. & 2006 \\
\hline Alternativní učebnice pro gymnázia - Mechanika & Nečas T. & 2008 \\
\hline $\begin{array}{l}\text { Mimoškolní astronomické vzdělávání v rámci hvězdáren } \\
\text { a planetárií }\end{array}$ & Ledvinka S. & 2009 \\
\hline
\end{tabular}

Tab. 9: Pedagogická fakulta Masarykovy univerzity v Brně

\begin{tabular}{|c|c|c|}
\hline Název práce & $\begin{array}{c}\text { Jméno } \\
\text { autora/autorky }\end{array}$ & $\begin{array}{c}\text { Rok } \\
\text { obhajoby }\end{array}$ \\
\hline $\begin{array}{l}\text { *Obsahová dimenze kurikula vzdělávání učitelů } \\
\text { př́rodovědných predmětů na 2. stupni } Z \check{S} \text { a } S S^{20}\end{array}$ & Škrabánková J. & 2005 \\
\hline Dovednosti žáků ve výuce fyziky na základni škole & Medková I. & 2010 \\
\hline 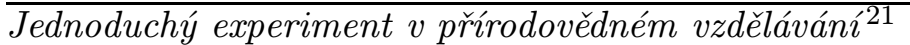 & Novák P. & 2013 \\
\hline
\end{tabular}

Tab. 10: Přírodovědecká fakulta Ostravské univerzity v Ostravě

\begin{tabular}{|c|c|c|}
\hline Název práce & $\begin{array}{c}\text { Jméno } \\
\text { autora/autorky }\end{array}$ & $\begin{array}{c}\text { Rok } \\
\text { obhajoby }\end{array}$ \\
\hline $\begin{array}{l}\text { Termodynamika nevratných procesů pro žáky základních } \\
\text { škol }\end{array}$ & Kubincová L. & 2009 \\
\hline $\begin{array}{l}\text { Počitačem podporovaná výuka fyziky v tématu fázové } \\
\text { změny }\end{array}$ & Mazurek J. & \\
\hline$\overline{I C T \text { v učivu elektromotorů na střední škole }}$ & Novák I. & \\
\hline Elektrická vodivost látek v učivu fyziky na základní škole & Půlkrábek V. & \\
\hline $\begin{array}{l}\text { Vytváření klíčových kompetencí v molekulové fyzice } \\
\text { a termice, jejich ověrení na střední škole }\end{array}$ & Smyček P. & \\
\hline $\begin{array}{l}\text { *Multimediální výukový program pro tematický celek Ter- } \\
\text { mika na základních školách }\end{array}$ & Cal & 2010 \\
\hline $\begin{array}{l}\text { ICT a hodnocení žáků jako motivační faktory při přípravě } \\
\text { žáků na vyučování }\end{array}$ & Foltýnová J. & \\
\hline Distanční studium fyziky na středni škole & Masná M. & \\
\hline $\begin{array}{l}\text { Multimediální vzdělávací program Optické jevy } \\
v \text { atmosfére }\end{array}$ & Peroutová A. & \\
\hline Nanotechnology in high school curriculum & Budzik S. & 2011 \\
\hline $\begin{array}{l}\text { Průřezové téma Environmentální výchova ve fyzice na } \\
\text { základni škole }\end{array}$ & Olšovský P. & \\
\hline Aplikace biomechaniky do výuky fyziky na $Z \bar{S}$ & Špetíková P. & \\
\hline Konstruktivismus ve výuce mechaniky na gymnáziu & Veselá V. & \\
\hline $\begin{array}{l}\text { Tvorba testů z fyziky s vazbou na výstupy Rámcového } \\
\text { vzdělávacího programu pro základní vzdělávání }\end{array}$ & Mazurová V. & 2012 \\
\hline Pracovni sešit ve výuce fyziky na střední odborné škole & Kerlínová V. & 2013 \\
\hline
\end{tabular}

\footnotetext{
${ }^{18}$ Práce obhájené na Pedagogické fakultě Masarykovy univerzity (obor: pedagogika) jsou uvedeny v tab. 9, která následuje za Prŕrodovědeckou fakultou Masarykovy univerzity.

${ }^{19} \mathrm{~V}$ následujících tabulkách je použito toto označení: * Práce nebyla analyzována, protože není dostupná. ${ }^{* *}$ Práce byla analyzována, ale není dostupná v elektronické podobě.
} 
Tab. 11: Pedagogická fakulta Univerzity Hradec Králové

\begin{tabular}{|c|c|c|}
\hline Název práce & $\begin{array}{c}\text { Jméno } \\
\text { autora/autorky }\end{array}$ & $\begin{array}{c}\text { Rok } \\
\text { obhajoby }\end{array}$ \\
\hline Vědecké poznatky jako obsah úloh pro talentované žáky & Cvrček M. & 2007 \\
\hline * Matematika a řešeni náročnějšich fyzikálních úloh & Jarešová M. & \\
\hline Pojem energie ve fyzikálním vzdělávání & Musílek M. & 2009 \\
\hline Motivace žáků $k$ fyzice na stupni základního vzdělání & Ṡtefančínová I. & \\
\hline $\begin{array}{l}\text { Interaktivní učebnice Zrak a zvuk ve výuce na střední } \\
\text { škole }\end{array}$ & Kordek D. & 2010 \\
\hline Prefyzika & Cesáková J. & 2011 \\
\hline Biologie jako zdroj motivace ve výuce fyziky & Pekařová J. & \\
\hline Geografie a fyzika - motivace a aplikace ve výuce fyziky & $\begin{array}{l}\text { Klapková- } \\
\text {-Dymešová P. }\end{array}$ & 2012 \\
\hline $\begin{array}{l}\text { Integrace poznatkư v přírodovědném vzdělávání základního } \\
\text { školství }\end{array}$ & Hejsková P. & 2013 \\
\hline *Modelování ve výuce fyziky & Horálek J. & \\
\hline Laboratorní práce na gymnáziu & $\begin{array}{l}\text { Reháková- } \\
\text {-Kubištová, M. }\end{array}$ & \\
\hline * Experimentálni podpora výuky astrofyziky & Šlégr J. & \\
\hline
\end{tabular}

Tab. 12: Pedagogická fakulta Západočeské univerzity v Plzni

\begin{tabular}{|c|c|c|}
\hline Název práce & $\begin{array}{c}\text { Jméno } \\
\text { autora/autorky }\end{array}$ & $\begin{array}{c}\text { Rok } \\
\text { obhajoby }\end{array}$ \\
\hline $\begin{array}{l}\text { Simulace galaktické dynamiky a jejich využití ve výuce } \\
\text { fyziky }\end{array}$ & Schwarzmeier J. & 2007 \\
\hline $\begin{array}{l}\text { Využití distančního vzdělávání při výuce astronomie (Slu- } \\
\text { nečni soustava) }\end{array}$ & Nedoma J. & 2008 \\
\hline $\begin{array}{l}\text { Výuka fyziky žáků se speciálními vzdělávacími potřebami } \\
n a Z S S\end{array}$ & Bretfeldová H. & 2011 \\
\hline $\begin{array}{l}\text { Vytváření výukových modelů z vybraných oblastí } \\
\text { teoretické fyziky a jejich využiti ve vyučováni fyziky }\end{array}$ & Masopust P. & \\
\hline $\begin{array}{l}\text { Elektrické pole v látkovém prostředí ve středoškolské } \\
\text { fyzice a v základním vysokoškolském kurzu }\end{array}$ & Tomáš M. & \\
\hline Počítačové modely pro výuku elektroniky & Kratochvíl P. & 2012 \\
\hline $\begin{array}{l}\text { Fyzika živých systémů: Optika a termodynamika živých } \\
\text { systémů }\end{array}$ & Duršpek J. & 2013 \\
\hline $\begin{array}{l}\text { Využití interaktivních dotykových tabulí v Ceské } \\
\text { republice a ukázkové výukové téma na rozhraní fyziky } \\
\text { a informatiky }\end{array}$ & Kohout V. & \\
\hline $\begin{array}{l}\text { Didaktické aspekty rozvoje kreativity ve výuce fyziky na } \\
\text { základní škole }\end{array}$ & Meškan V. & \\
\hline
\end{tabular}


Tab. 13: Matematicko-fyzikální fakulta Univerzity Karlovy v Praze

\begin{tabular}{|c|c|c|}
\hline Název práce & $\begin{array}{c}\text { Jméno } \\
\text { autora/autorky }\end{array}$ & $\begin{array}{c}\text { Rok } \\
\text { obhajoby }\end{array}$ \\
\hline ** Evaluace výsledků fyzikálního vzdělávání na Ž̆ & Hejnová E. & 2004 \\
\hline "** Heuristické metody ve výuce fyziky na gymnáziu & Hronková J. & \\
\hline **Entropie na středoškolské úrovni & Prokšová J. & \\
\hline Výuka astronomie na středních školách & Pudivítr P. & \\
\hline $\begin{array}{l}\text { Moderní metody výuky - využití výpočetní techniky pro } \\
\text { výuku na středni škole }\end{array}$ & Kekule J. & 2005 \\
\hline $\begin{array}{l}\text { "** Využití moderních metod a prostředkü při praktické } \\
\text { výuce fyziky }\end{array}$ & Panoš M. & \\
\hline Fyzikální experimenty s běžným hardwarem & Sedláček J. & \\
\hline $\begin{array}{l}\text { A strategic development model for the educator role of the } \\
\text { biomedical physics-engineering academic in faculties of he- } \\
\text { alth science in Europe }\end{array}$ & Caruana C.J. & 2006 \\
\hline Zjištování parametrů kvality výuky fyziky & Żák V. & \\
\hline Netradični metody a formy fyzikálního vzdělávání & Broklová Z. & 2008 \\
\hline Tvorba testů pro středoškolskou fyziku a jejich ověřování & Kekule T. & \\
\hline $\begin{array}{l}\text { Výuka fyziky podporovaná prostředky elektronického } \\
\text { vzdělávání }\end{array}$ & Jílek M. & 2009 \\
\hline Grafy ve výuce fyziky & Kekule M. & \\
\hline Nové př́istupy $k$ výuce základů kvantové fyziky & Králík J. & \\
\hline Fyzikální vzdělávání žáků a učitelů v projektu Heuréka & Dvořáková I. & 2011 \\
\hline Multimediální podpora fyzikálního vzdělávání & Koupil J. & \\
\hline
\end{tabular}

Tab. 14: Přírodovědecká fakulta Univerzity Palackého v Olomouci

\begin{tabular}{llc}
\hline Název práce & $\begin{array}{c}\text { Jméno } \\
\text { autora/autorky }\end{array}$ & $\begin{array}{c}\text { Rok } \\
\text { obhajoby }\end{array}$ \\
\cline { 1 - 2 } Vybrané prekoncepty v oblasti př́rodovědného vzdělávání & Kainzová V. & \\
a jejich aplikace v integrovaném pojetí výuky & & \\
\cline { 1 - 2 } Vzdáleně ovládané experimenty ve výuce fyziky & Látal F. & \\
\cline { 1 - 2 } Meteorologie a klima ve výuce fyzice na základní škole & Miléŕ T. & \\
\hline
\end{tabular}

